\title{
DETERMINING FACTORS OF THE BENEFITS DERIVED FROM THE IMPLEMENTATION OF EN 9100 STANDARDS
}

\section{Carlos del Castillo-Peces, Carmelo Mercado-Idoeta, Camilo Prado-Román}

\section{Introduction}

The aerospace sector is one of the most important in global economy. The invoicing of the first 100 aerospace companies worldwide was in 2011665,970 million dollars, which represents $5 \%$ of the world's gross domestic product (PwC, 2012). In Spain, this sector is equally important, since according to the data of the year 2011 (DBK, 2012), it represents the fifth industry of the sector in the European Union, both due to the employment level $(40,200$ employees) and the annual invoicing $(6,715$ million euros, which represent approximately $6 \%$ of Europe's total invoicing). Aerospace sector is clearly exports-oriented, since nearly $75 \%$ of its total invoiced in the year arises from exporting.

By contrast, the progressive complexity of the systems employed in this sector, and the greater importance of the projects to be undertaken have caused that nowadays there is a lack of end-product manufacturers (that is airplanes, helicopters, satellites, etc.). On the contrary, the development of these products is the result of the collaboration of a number of systems and subsystems manufacturers, together with other specialized companies, which leads to considerable subcontracting relations, as well as a progressive internationalization of manufacturing and development activities (TEDAE, 2010). This degree of complexity, subcontracting and internationalization, along with the fact that "security" is a basic element supporting the activity of this sector, implies that aerospace products are subject to high demands regarding quality and reliability issues; hence the standards of quality in the sector are some of the most demanding in the industrial field (Grijalbo \& Prida, 2005). Standardization is a mechanism that favors exchange and international trade in today's global economy, removing the obstacles that arise from each country practices (Heras \& Boiral, 2013) and providing answers to the international character of the joint projects among companies located in different countries that are common in this industry.

The purpose of Quality Management Systems (QMS) is the quality continuous improvement not only in products/services, but also in all the processes in the firms, allowing customers satisfaction and encouraging the efforts and responsibility of everyone in the organization (Fonseca, 2013). Among these QMS we can cite the quality assurance standards, being the ISO 9000 standard the most widespread. This standard is a series of norms that strive to standardize processes, functions, and roles but do not necessarily prescribe goals or results (Guler et al., 2002; Braun, 2005). The main purpose of ISO 9001 is to give confidence in the organization's ability in order to provide consistently conforming products to the requirements of its customers (Pawliczek \& Piszczur, 2013). In view of all the foregoing, quality assurance standards in the aerospace sector are certainly widespread, both the ISO 9001 Standards, and the series of EN 9100 Standards, that takes into account specific aspects of this industry with respect to ISO 9001, which is of more generic nature.

The implementation of these standards of quality assurance is associated with a series of temporary and organizational monetary investments, both initial and maintenance investments, which is expected to maximize its return (Whitford \& Bird, 1996). Nonetheless, these investments are not always offset with positive results, which sometimes may be scarce as indicated by previous studies about ISO 9001 (Quazi et al., 2002; Martínez-Costa et al., 2009; Boiral \& Amara, 2009). All this seems to indicate that it is not enough to obtain the certification associated to these Standards, 
nonetheless there are certain factors that may condition these positive results (Lee et al., 2009; Psomas et al., 2010; Boiral, 2011). Logically, the implementation of EN 9100 supposes higher costs than those derived from implementing ISO 9001 generic standards, since it includes a number of additional requirements characteristic of the aerospace sector. In theory, to be adhered to said standards should be compensated by earning higher profits, as compared to those that could arise from implementing ISO 9001.

Previous studies in the field of EN 9100 Standards are not very numerous; some of them focus on describing the standards' general characteristics, as well as their main differences with respect to ISO 9001 (Beltran, 2002; Juny, 2005; Gutierrez, 2008); others describe the level of implementation of the EN 9100 Standards, which in major manufacturers and suppliers of the sector is widespread, while it is more unequal in second and third level suppliers (Grijalbo \& Prida, 2005); other studies include models and guidelines to adhere to these standards (IAT, 2003). Finally, other studies describe how was EN 9100 implemented in some of the major aerospace companies, as EADS, SENER, etc. (Murga, 2002; Vilar, 2003; Mugarra, 2005). However, none of them analyzes specifically the benefits derived from the implementation of EN 9100, nor their determining factors. Regarding ISO 9001 Standards, which was its predecessor in the sector, it has indeed been subject of multiple studies, although none of them makes specific reference to the aerospace sector.

Based on the foregoing, this research aims to begin covering the virtual lack of studies about the results arising from the implementation of quality assurance standards in this sector. In particular, the objective of the research involves analyzing whether the appearance of the various positive effects that may arise as a result of implementing EN 9100 Standards is influenced by the following factors: a) size of the company; b) implementation of EN 9100 seniority; c) prevailing type of motivation (external and/or internal) to adhere to such standards.

Following this introduction, which provides a context for the basic elements of the study, there is a description of the theoretical framework of the research under the second heading, including basic aspects of quality management in the aerospace industry and a review of the literature available that is relevant to these standards. In the third section there is a description of the samples and methodology used, and detailed information of results and conclusions is provided in sections four and five respectively.

\section{Conceptual Framework}

Currently, the high levels of competitiveness and globalization applicable to almost all sectors, have led to an extensive development of the quality management concept as a strategic approach to address quality in a company, which is based on customer-oriented, continuous improvement, focus on people and global vision principles of the organization (Camison et al, 2009). Ultimately, quality management systems enable companies to implement management tools in order to establish policies and responsibilities, allocate resources, and identify key activities (Criado \& Calvo, 2009).

\subsection{Quality Management in the Aerospace Sector}

As aforementioned, the aerospace industry has always been at the forefront of the development of quality management systems, since their standards are significantly higher than those found in other industrial sectors, with the exception of the automotive sector (Gutierrez, 2008). The "Self-assessment scheme" constituted the first step in the evolution of quality systems in the industry. Subsequently, companies in the sector have used the "second part schemes", which consist on auditing suppliers' quality systems based on each customer's own criteria and methods. This system involves elevated costs for the sector, since the same company may be audited regularly by several entities, thus multiplying the costs that are incurred.

In order to increase efficiency, a tendency towards the development and adoption of systems based on "third part schemes" took place during the nineties, among them stands out the ISO 9001 Standards that spread within the sector as the only quality management system that should be taken into consideration. Nevertheless, these standards did not entirely apply to the specificities of the aerospace industry, hence the majority of the most important companies in the sector continued to produce their own supplements 
to the standards, with the consequent proliferation of the requirements established for the providers, which again caused the same problems resulting from the second part schemes (Grijalbo \& Prida, 2005). In December 1998 the largest providers, manufacturers and commercial associations of America, Europe and Asia joint together to form the International Aerospace Quality Group (IAQG), that in 1999 promoted the EN 9100 Standards family, with the purpose of standardizing the additional requirements of the sector at a more concrete level than ISO 9001.

The EN 9100 Standards (AS 9100 in America and SIAC 9100 in Asia), includes both the requirements derived from the ISO 9001 and 83 specific additional requirements for the aerospace industry, giving special importance to the areas that were considered could have a higher impact on security and reliability of aerospace products, such as: design, purchasing, process control, inspection and testing, and control of non-compliances. These additional requirements aim at the reduction of variability in the production of goods, for which companies must have continuous improvement systems that enable a more solid interaction between processes, and therefore reduce the chances that the product is outside preestablished limits.

In December 2012 the OASIS database of IAQG, where the companies that have implemented these standards were registered, hold 14,300 headquarters of certified companies around the world, of which 448 were located in Spain (OASIS database contained certified headquarters, hence a company with several offices will appear more than once, which is common for large companies; therefore, the number of certifications on the database exceeds the total number of companies in this sector both globally and in Spain).

The group of EN 9100 Standards of generic content, issued by the IAQG, is composed by the following (IAQG, 2009):

- EN 9100 - Model for quality assurance in design, development, production, installation and servicing.

- EN 9110 - Aerospace Series, Model for quality assurance applicable to maintenance organizations.

- EN 9120 - Aerospace Series, Model for quality assurance applicable to Stockist Distributors.

\subsection{Literature Review}

As specified in the introduction, there are few papers related to EN 9100 Standards, and none of them refers to the effective results derived from their implementation. Regarding ISO 9001 Standards family, it has been subject to multiple studies, although none of them makes specific reference to the aerospace sector. Given the objective of this research, a revision has been made to the main studies that specifically or among other issues, refer to the positive effects generated by the adherence to ISO 9001 , and especially what may be the influence of the factors that shall be considered in regards to EN 9100, i.e., the size of the company, the seniority in the implementation of these standards, as well as the prevailing type of motivation [external an or internal] to adhere to such standards.

\section{a) Positive Effects Generated when Implanting ISO 9001 Standards}

In general, it may be noted that most studies conclude that ISO 9001 entails beneficial effects for the companies; notwithstanding the foregoing, and even though they are a minority, there are other studies that do not reflect these positive effects, or at least not in all cases or circumstances (Quazi et al., 2002; MartínezCosta et al., 2009; Boiral \& Amara, 2009).

In regards to the positive results generated by the adherence to the standards, it should be remarked that diverse studies (Sampaio et al., 2009; Tari et al., 2012), classified them into positive effects concerning "internal aspects", and "external aspects". Based on the conclusions of these studies, these positive effects could be itemized as presented on table 1.

Comparing the relative importance of the two types of benefits associated with the implementation of ISO 9001, there are some previous researches that prioritize the positive effects on internal aspects (Bhuiyan \& Alan, 2005; Martínez-Costa et al., 2008; Lo et al., 2009), whereas other studies emphasizes those related to external aspects (Benner \& Veloso, 2008; Dick et al., 2008). Notwithstanding the foregoing, most of the previous studies reveal positive results both of internal and external nature (Rodríguez-Escobar et al., 2006; Calisir, 2007; Lo \& Chang, 2007). 


\section{Tab. 1: Typology of positive effects resulting from adherence to ISO 9001}

\section{INTERNAL ASPECTS}

\begin{tabular}{l|l}
\hline $\begin{array}{l}\text { Related to organizational } \\
\text { processes }\end{array}$ & $\begin{array}{l}\text { Production management control, definition of responsibilities and rules, } \\
\text { process documentation, etc. }\end{array}$ \\
\hline $\begin{array}{l}\text { Related to operational } \\
\text { execution }\end{array}$ & $\begin{array}{l}\text { Efficient use of resources, inspection and logistic cost decrease, decline } \\
\text { in nonconformity, etc. }\end{array}$ \\
\hline Related to HR & Job satisfaction, work team dynamics, employee suggestion systems, etc. \\
\hline \multicolumn{2}{c}{ EXTERNAL ASPECTS } \\
\hline $\begin{array}{l}\text { Related to finance } \\
\text { and marketing }\end{array}$ & Sales volume, market share, sales-per-employee ratio, etc. \\
\hline $\begin{array}{l}\text { Related to customer } \\
\text { relations }\end{array}$ & Client retention, number of complaints, public image, etc. \\
\hline
\end{tabular}

b) Influence of the Companies' Size Factor on the Positive Effects Derived from Implementing ISO 9001 Standards

Previous researches are not conclusive concerning the influence of companies' size factor on the beneficial effects of implementing ISO 9001. In this regard, there are studies which indicate that in smaller companies it is more difficult to obtain positive results, since they usually lack certain internal resources which are important to have a successful adherence (at least with respect to internal benefits), and furthermore, the initial costs and investments necessary to obtain the certification are proportionally more significant in comparison with larger companies (Gustafsson et al., 2001; Rodríguez-Escobar et al., 2006).

Nevertheless, it is also possible to find numerous studies which indicate that the benefits are similar regardless of the size, since the conditions to obtain these benefits are more related to the intensity of the implementation of ISO 9001 than to the size of the companies, although in smaller companies it could be slower (Terziovski et al., 2003; Briscoe et al., 2005; Psomas et al., 2010), and in some cases the benefits perceived in these companies may be even higher taking into consideration that the starting point in the field of quality management tends to be lower, hence the opportunities for improvement are greater (Gotzamani \& Tsiotras, 2001).

c) Influence of the Time Factor (Standards Adherence Seniority) on the Positive Effects Derived from Implementing ISO 9001 Standards
Once again, previous researches are not conclusive concerning the influence of this factor on the beneficial effects of implementing ISO 9001. In this regard, there are studies which reveal that time is a positive factor for the appearance of the aforementioned beneficial effects caused by the adherence to ISO 9001 (Climent, 2005; Martinez-Costa et al., 2008; Lo et al., 2009). According to these studies, the principles underlying ISO 9001 as a quality management system need certain time to be internalized within the companies, and obtain the benefits sought in all of their intensity.

Nevertheless, there are other studies which state that time has no influence whether companies obtain positive effects from ISO 9001, or at least not in all cases (Terziovski et al., 2003; Gotzamani et al., 2006; Lee et al., 2009), or that it may even cause a reduction on the initial benefits derived from the implementation of said standards (Casadesus \& Karapetrovic, 2005; Sampaio et al., 2009; Karapetrovic et al., 2010). According to these studies, when the intended purpose is almost exclusively to obtain the certification in order for the company not to be excluded from the market, this benefit appears immediately after implementing these standards.

d) Influence of the Prevailing Motivation (External or Internal) for the Adherence to ISO 9001 Standards Factor, on the Positive Effects Derived from Their Implementation

According to previous researches, the motivations for the adherence may refer to "external aspects", such as image improvement 
and market position of the company, aspects regarding commercial, financial and customers' relations nature, as well as "internal aspects" such as the improvement of organizational, execution of operations, and human resources management processes of the company (Boiral \& Amara, 2009; Sampaio et al., 2009).

Furthermore, it has been noted that there is a majority of researches where the motivations related to "external aspects" are the ones that prevail (Bhuiyan \& Alam, 2005; RodríguezEscobar et al., 2006; Martínez-Costa et al., 2008), compared to those which considered that both types of aspects are balanced, or even those where "internal aspects" prevail (Chang \& Lo, 2005; Magd, 2008; Fotopoulos \& Psomas, 2010).

Likewise, attention must be drawn to the fact that, in regards with previous studies related to ISO 9001 on the possible relation between the prevailing type of motivation for obtaining the adherence [external and/or internal], and the results, the studies stating that a higher level of external motivation entails a greater level of benefits are an exception (Bhuiyan \& Alam, 2005), given that, in general there is an agreement in which if the adherence to the standards is due to an attempt to improve internal aspects of the company, instead of an external pressure (customers/regulators), or to obtain improvement on merely external aspects (image improvement / following a trend), the global benefits observed after the implementation of ISO 9001 are greater (Rodríguez-Escobar et al., 2006; Sampaio et al., 2009; Prajogo, 2011). According to these researches, if the only motivations for the adherence to ISO 9001 are those of external character, there is a high risk that the company shall not acquire new capacities nor obtain no sustainable competitive advantage, except for not seeing itself excluded from the market thanks to the certification; nevertheless, when motivations of internal type exist, these are the ones that can generate a greater level of implementation of the principles of these standards, which should render operative and organizational improvements, which derive in an improvement of quality and customers satisfaction, which shall later result in financial improvements.

\section{Research Methodology}

\subsection{Sample}

The research was addressed to the Spanish aerospace sector, hence based on the criteria listed hereafter; the population subject to the investigation was defined by 317 companies.

This sector is composed of a great diversity of companies, both regarding size and business specialization, so in order to elaborate the census of the companies to be studied, the National Classification of Economic Activities (CNAE according to its Spanish acronym), could not be employed since it lacks one or more categories that compile all the companies belonging to the sector. Therefore, it has been necessary to resort to a compilation of specific databases comprising the companies of the sector. The first census to be considered was TEDAE which at the end of 2010 was the cornerstone association in Spain, since its 52 members, which include the most important companies of the aerospace sector, combined $91 \%$ of the turnovers. The second database that was taken into consideration was OASIS (this database registers all the aerospace companies adhered to EN 9100). Finally, other databases related to this industry have been considered for complementary purpose. After eliminating duplications, the final population subject to the analysis is reflected on table 2 , detailed hereinafter:

\section{Tab. 2: Survey population breakdown according to census}

\begin{tabular}{|c|c|c|c|c|}
\hline \multirow{2}{*}{ CENSUS } & \multicolumn{2}{|c|}{ FIRMS IN AEROSPACE INDUSTRY } & \multirow{2}{*}{$\begin{array}{l}\text { AUXILIARY } \\
\text { BUSINESSES }\end{array}$} & \multirow{2}{*}{ TOTAL } \\
\hline & $\begin{array}{c}\text { AVIATION } \\
\text { SUBSECTOR }\end{array}$ & $\begin{array}{l}\text { AEROSPACE } \\
\text { SUBSECTOR }\end{array}$ & & \\
\hline TEDAE & 34 & 6 & 12 & 52 \\
\hline OASIS & 96 & 7 & 57 & 160 \\
\hline OTHER & 83 & 5 & 17 & 105 \\
\hline TOTAL & 211 & 18 & 85 & 317 \\
\hline
\end{tabular}




\subsection{Questionnaire}

In order to develop the questionnaire, the first step was to elaborate a draft analyzing previous researches concerning the ISO 9001 (Gotzamani \& Tsiotras, 2001; Mercado et al., 2005), classifying the possible motivations for adherence to EN 9100, as well as the positive effects perceived from the implementation, based on the different "internal" and "external" aspects reflected on table 1 . This draft was subject to a pretest elaborated by experts in the field belonging to two of the participating companies (Airbus Spain and Iberia LAE Maintenance); an in-depth interview was held with both experts. Once their opinions were incorporated, the final version of the questionnaire was set forth. Subsequently, the questionnaire was sent by postal mail and e-mail to the directors of quality of all the 317 selected companies.
After finishing the process of questionnaire reception, it was determined that there were 126 valid companies, which represents $39.7 \%$ of the total population (317 companies). Furthermore, it should be noted that the EN 9100 Standards are widely implemented on the organizations that have completed the questionnaire $(72.2 \%$ of the companies, that is 91 of them), with an adherence seniority higher than five years in $88 \%$ of the cases, and an elevated level of intensity in the implementation, since $75 \%$ of the companies have adhered all their processes to the standards. Both aspects, seniority and intensity of the implementation, reinforce the validity of the answers obtained in the questionnaires received. Afterwards, the data sheet of the study contained in table 3 was elaborated based on all this information:

\section{Tab. 3: Data sheet}

\begin{tabular}{l|l} 
Universe & Spanish firms in the aerospace industry \\
\hline Sampling technique & Random: the survey was sent to all entities in the universe \\
\hline Methodology & Mail and online survey \\
\hline Individuals receiving the survey & Director of Quality Assurance or equivalent \\
\hline Population & 317 \\
\hline Sample size & 126 \\
\hline Confidence level & $95 \%[z=1.96 ; p=q=0.5]$ \\
\hline Sampling error & $6.8 \%$ \\
\hline Time period & From October 1,2011 to January 31,2012 \\
\hline
\end{tabular}

\subsection{Variables and Model Proposed}

To be able to analyze the influence of the different factors considered in this research on the appearance of the different positive effects derived from the implementation of EN 9100 Standards, a multiple linear regression model has been designed; the variables considered are the following ones:

Dependent Variables Y: different benefits derive from the EN 9100 Standards, according to the typology contained on the table 1 of this study. According to the answers obtained in the questionnaire provided to the participating companies, these variables can take the following values: 1 - very low, 2 - low, 3 - medium, 4 - high and 5 - very high:

Variable $\mathrm{Y}_{1}$ : internal positive effects related to organizational processes (OrgEN).

Variable $\mathrm{Y}_{2}$ : internal positive effects concerning execution of operations (ExecEN).

Variable $Y_{3}$ : internal positive effects related to human resources (HrEN).

Variable $Y_{4}$ : external positive effects related to financial and commercial aspects (FinComEN).

Variable $\mathrm{Y}_{5}$ : positive external effects related to aspects of customers' relationship (ClienEN). 
Independent variables $\mathrm{X}$ :

Variable $\mathrm{x}_{1}$ : Size of the company (Size). According to the answers obtained in the questionnaire provided to the participating companies, this variable can take the following values: 1 - small, 2 - medium, 3 - large (based on the criteria of the EU recommendation 2003/361/EC).

Variable $\mathrm{x}_{2}$ : Seniority in the adherence to EN 9100 Standards (Sen). According to the answers obtained in the questionnaire provided to the participating companies, these variables can take the following values: 1 - Seniority not exceeding 3 years, 2 - Seniority exceeding 3 years.

Variable $\mathrm{x}_{3}$ : Prevailing type of motivation (external and/or internal) for the adherence
(TypeMot). According to the answers obtained in the questionnaire provided to the participating companies, these variables can take the following values: 1 - if the "external" motivations are predominant, 2 - if "internal" motivations are predominant.

Based on these variables the following model of multiple linear regressions has been designed, including the variable $u_{i}$ that is the statistic error:

$$
\begin{aligned}
& Y_{i}=\beta_{0}+\beta_{1} * x_{1, i}+\beta_{2} * x_{2, i}+ \\
& +\beta_{3} * x_{3, i}+u_{i} \\
& \text { Effect }_{I}=\beta_{0}+\beta_{1} * \text { Size }_{1, i}+\beta_{2} * \\
& * \text { Sen }_{2, i}+\beta_{3} * \text { TypeMot }_{3, i}+u_{i}
\end{aligned}
$$

\begin{tabular}{|c|c|c|c|c|c|c|}
\hline \multirow{2}{*}{$\begin{array}{l}\text { Dependent } \\
\text { variable }\end{array}$} & \multirow{2}{*}{$\begin{array}{l}\text { Independent } \\
\text { variable }\end{array}$} & \multicolumn{2}{|c|}{$\begin{array}{l}\text { Non standardized } \\
\text { coefficients }\end{array}$} & \multirow{2}{*}{$\begin{array}{c}\begin{array}{c}\text { Standardized } \\
\text { coefficients }\end{array} \\
\text { Beta }\end{array}$} & \multirow{2}{*}{$\mathbf{t}$} & \multirow{2}{*}{ Sig. } \\
\hline & & Beta & $\begin{array}{c}\text { Standard } \\
\text { error }\end{array}$ & & & \\
\hline \multirow{4}{*}{ OrgEN } & [Constant] & 0.428 & 0.546 & & 0.784 & 0.436 \\
\hline & Size & 0.051 & 0.112 & 0.450 & 0.454 & 0.651 \\
\hline & Seniority & 1.132 & 0.259 & 0.437 & 4.379 & 0.000 \\
\hline & Type of motivation & 0.320 & 0.172 & 0.185 & 2.855 & 0.067 \\
\hline \multirow{4}{*}{ ExecEN } & [Constant] & 0.070 & 0.614 & & 0.114 & 0.910 \\
\hline & Size & 0.216 & 0.126 & 0.168 & 1.713 & 0.091 \\
\hline & Seniority & 0.800 & 0.291 & 0.274 & 2.751 & 0.007 \\
\hline & Type of motivation & 0.693 & 0.194 & 0.356 & 3.575 & 0.001 \\
\hline \multirow{4}{*}{$\mathrm{HrEN}$} & [Constant] & 0.781 & 0.565 & & 1.381 & 0.171 \\
\hline & Size & -0.195 & 0.116 & -0.163 & -1.679 & 0.097 \\
\hline & Seniority & 0.606 & 0.268 & 0.222 & 2.265 & 0.026 \\
\hline & Type of motivation & 0.744 & 0.178 & 0.410 & 4.171 & 0.000 \\
\hline \multirow{4}{*}{ FinComEN } & [Constant] & 2.314 & 0.493 & & 4.696 & 0.000 \\
\hline & Size & -0.049 & 0.101 & -0.053 & -0.488 & 0.627 \\
\hline & Seniority & 0.525 & 0.233 & 0.247 & 2.252 & 0.027 \\
\hline & Type of motivation & 0.218 & 0.155 & 0.154 & 1.406 & 0.164 \\
\hline \multirow{4}{*}{ ClienEN } & [Constant] & 1.875 & 0.458 & & 4.093 & 0.000 \\
\hline & Size & -0.041 & 0.094 & -0.046 & -0.440 & 0.661 \\
\hline & Seniority & 0.664 & 0.217 & 0.323 & 3.063 & 0.003 \\
\hline & Type of motivation & 0.277 & 0.144 & 0.202 & 1.920 & 0.059 \\
\hline
\end{tabular}

\section{Tab. 4: Results obtained for the model: independent variable coefficients}




\section{Results}

Table 4 presents the results obtained from the model, in particular the coefficients of the independent variables (size, seniority, and type of motivation) regarding the dependent variables (each of the positive effects). In this table we include the coefficients standardized and the non-standardized of our model variables; these coefficients indicate the weight of the independent variables regarding each dependent variable, that is, each positive effect from the Standard. We include too, the $t$ value (t) and the signification (sig.); these indicate if each independent variable is significant or not regarding each dependent variable. The variables are significant if the $t$ value $(t)$ is bigger than two ( $\mathrm{t}>2$ ) and a signification (sig.) smaller or equal than 0.05 .

The final model with the significant variables would be as follows:

$$
\begin{aligned}
& \text { OrgEN }=0.428+0.437(\mathrm{Sen})+ \\
& +0.185(\text { TypeMot })+u \\
& \text { ExecEN }=0.070+0.274(\mathrm{Sen})+ \\
& +0.356(\text { TypeMot })+u \\
& \text { HrEN }=0.781+0.222(\mathrm{Sen})+ \\
& +0.410(\text { TypeMot })+u \\
& \text { FinComEN }=2.314+0.247(\mathrm{Sen})+u \\
& \text { ClienEN }=1.875+0.323(\mathrm{Sen})+ \\
& +0.202(\text { TypeMot })+u
\end{aligned}
$$

Therefore, table 4 reveals the following results regarding the independent variables of the model:

The "size of the company" is a variable with at $<2$ for the raised models, hence it is accepted that this variable is non-significant for each one of the internal positive effects (organizational, execution of operations, and human resources management processes), as well as for the external ones (financial-commercial, and customers management processes), thus it has been excluded from the regression model elaborated.

The "seniority of the adherence to EN 9100 " is a variable with a $t>2$ for the raised models, hence it is accepted that this variable is significant for each one of the internal positive effects (organizational, execution of operations, and human resources management processes), as well as for the external ones (financialcommercial, and customers management processes). When obtaining a positive sign, an increase of this independent variable shall produce an increase (in rate of growth) on the dependent variable, being the rest constant. That is, an increase in 1 unit in the "seniority to the adherence to EN 9100" shall produce an increase of $43.70 \%$ on the internal effect "OrgEN", of $27.40 \%$ on the internal effect "ExecEN", of $22.22 \%$ on the internal effect "HrEN", of $24.70 \%$ on the external effect "FinComEN" and of $32.30 \%$ on the external effect "ClienEN". The higher the value of the variable, the greater the internal and external effects shall be.

The "prevailing type of motivation (external and/or internal) for the adherence" is a variable with a $\mathrm{t}>2$, hence it is accepted that this variable is significant for each one of the internal positive effects (organizational, execution of operations, and human resources management processes), as well as for the external ones regarding customers management. When obtaining a positive sign, an increase of this independent variable shall produce an increase (in rate of growth) on the dependent variable, being the rest constant. That is, an increase in 1 unit in the "prevailing type of motivation" shall produce an increase of $18.50 \%$ on the internal effect "OrgEN", of $35.60 \%$ on the internal effect "ExecEN", of $41.00 \%$ on the internal effect "HrEN", and of $20.20 \%$ on external effect "ClienEN" (we accept type of motivation on external effect "ClienEN" because it has a t very near 2). The higher the value of the variable, which means internal motivations prevail, the greater the internal and external effects shall be.

On the contrary, the "prevailing type of motivation [external and/or internal] for the adherence" is a variable with one $t<2$ $(t=1.406)$, only for financial-commercial external effects, hence it is considered that this variable is non-significant for the dependent variable "FinComEN". Table 5 presents an overview of the significance of variables in the model.

Finally, table 6 contains the corresponding coefficient of determination $\left(R^{2}\right)$; this is a number that indicates how the data fit in our model. It provides a measure of the percentage of variability of each dependent variable (internal and external "positive effect"), that is explained by each significant independent variable. Based on the results described in this table, the coefficient of determination $R^{2}$ has a value that fluctuates between $20 \%$ and 


\section{Tab. 5: Significance overview}

\begin{tabular}{|c|c|c|}
\hline Dependent variable & Independent variable & Sig. \\
\hline \multirow{3}{*}{ OrgEN } & Size & $x$ \\
\hline & Seniority & $\sqrt{ }$ \\
\hline & Type of motivation & $\sqrt{ }$ \\
\hline \multirow{3}{*}{ ExecEN } & Size & $x$ \\
\hline & Seniority & $\sqrt{ }$ \\
\hline & Type of motivation & $\sqrt{ }$ \\
\hline \multirow{3}{*}{$\mathrm{HrEN}$} & Size & $\mathrm{x}$ \\
\hline & Seniority & $\sqrt{ }$ \\
\hline & Type of motivation & $\sqrt{ }$ \\
\hline \multirow{3}{*}{ FinComEN } & Size & $x$ \\
\hline & Seniority & $\sqrt{ }$ \\
\hline & Type of motivation & $x$ \\
\hline \multirow{3}{*}{ ClienEN } & Size & $x$ \\
\hline & Seniority & $\sqrt{ }$ \\
\hline & Type of motivation & $\sqrt{ }$ \\
\hline
\end{tabular}

Source: own

\section{Tab. 6: Coefficient of determination}

\begin{tabular}{|c|c|c|c|c|c|}
\hline $\begin{array}{c}\text { Dependent } \\
\text { variable }\end{array}$ & $\begin{array}{l}\text { Independent } \\
\text { variable }\end{array}$ & $\begin{array}{l}\text { Standardized } \\
\text { coefficients }\end{array}$ & $\mathbf{R}^{2}$ & $\begin{array}{c}\text { Correlation between } \\
\text { dependent and inde- } \\
\text { pendent variable }\end{array}$ & $\begin{array}{l}\text { Explained } \\
\text { Variance }\end{array}$ \\
\hline \multirow{3}{*}{ OrgEN } & Size & 0.450 & \multirow{3}{*}{$25.30 \%$} & 0.029 & not significant \\
\hline & Seniority & 0.437 & & 0.467 & $20.41 \%$ \\
\hline & Type of Motivation & 0.185 & & 0.258 & $4.77 \%$ \\
\hline \multirow{3}{*}{ ExecEN } & Size & 0.168 & \multirow{3}{*}{$25.80 \%$} & 0.155 & not significant \\
\hline & Seniority & 0.274 & & 0.328 & $8.99 \%$ \\
\hline & Type of Motivation & 0.356 & & 0.399 & $14.20 \%$ \\
\hline \multirow{3}{*}{$\mathrm{HrEN}$} & Size & -0.163 & \multirow{3}{*}{$27.80 \%$} & -0.174 & not significant \\
\hline & Seniority & 0.222 & & 0.296 & $6.57 \%$ \\
\hline & Type of Motivation & 0.410 & & 0.449 & $18.41 \%$ \\
\hline \multirow{3}{*}{ FinComEN } & Size & -0.052 & \multirow{3}{*}{$20.10 \%$} & -0.062 & not significant \\
\hline & Seniority & 0.247 & & 0.274 & $20.10 \%$ \\
\hline & Type of Motivation & 0.154 & & 0.196 & not significant \\
\hline \multirow{3}{*}{ ClienEN } & Size & -0.046 & \multirow{3}{*}{$27.00 \%$} & -0.058 & not significant \\
\hline & Seniority & 0.323 & & 0.358 & $11.56 \%$ \\
\hline & Type of Motivation & 0.202 & & 0.256 & $5.17 \%$ \\
\hline
\end{tabular}


$27.80 \%$ (for results that are significant), which indicates that the independent variables of the "seniority" and "prevailing type of motivation for adherence" models, explain between $20 \%$ and $27.80 \%$ of the variability of dependent variables (both internal and external "positive effects"). With the aim of identifying the explained variance of each construct (dependent variable) by each independent variable (the percentage of the $R^{2}$ coefficient explained for each one), we proceeded to break down the explained variance by variable. This allow us make up a "ranking" of "predictive power" of each independent variable. The explained variance is the result of multiplying the correlation between dependent and independent variables by the standardized coefficient of each independent variable (size, seniority, and type of motivation).

\section{Discussion}

This study has sought to analyze how certain factors may influence the internal and external benefits derivatives from implementing the EN 9100 Standards. These factors are: the size of the company, the seniority of the implementation of EN 9100 and the prevailing type of motivation (external and/or internal) for the adherence; to that end the companies of the Spanish aerospace sector have been studied. Accordingly, the conducted multiple linear regression states the following:

The "seniority of the adherence to EN 9100 Standards" is a significant variable for each one of the internal positive effects (organizational, execution of operations, and human resources management processes), as well as for the external ones (financialcommercial, and customers management processes), considered for this research $(\mathrm{t}>2)$. Ultimately, the longer the time elapsed since the implementation of the standards, the greater the benefits derived from the adherence. This result follows the line of the studies of Climent (2005), Martinez-Costa et al. (2008) and Lo et al. (2009), where the positive influence of this factor is derived from the standards learning curve, as well as the necessary time to internalize within companies a series of context factors (commitment of all members of the company, customers-orientation, continuous improvement, employees training, etc.), necessary for obtaining the benefits sought with the adherence to EN 9100, in particular those related to internal aspects.
The "prevailing type of motivation (external and/or internal) for the adherence to EN 9100 Standards" is a significant variable for each one of the internal positive effects (organizational, execution of operations, and human resources management processes) considered for this study, as well as for the external effects of customers management $(t>2)$, in a manner that such effects shall be greater as long as the prevailing motivations for the implementation of EN 9100 are the pursuit of internal positive effect. This result agrees with the conclusions of the studies of Rodríguez-Escobar et al. (2006), Sampaio et al. (2009) and Prajogo (2011), where it has been indicated that the search for internal improvements is the motivation that can truly cause a real improvement on the quality of the company's performance, and therefore a greater level of positive effects derived from the adherence to these standards.

Nevertheless, the "size of the company" does not represent a significant variable for each one of the internal positive effects (organizational, execution of operations, and human resources management processes), as well as for the external ones (financialcommercial, and customers management processes) considered for the study $(t<2)$, that is, the level of achievement of these effect does not suffer significant variations when taking into consideration the size of the companies. This result is in line with the studies of Terziovski et al. (2003), Briscoe et al. (2005) and Psomas et al. (2010), which is coherent with the specificities of the aerospace sector, where security and quality of products has always being a fundamental characteristic for all the companies, regardless of their size.

\section{Conclusions}

The results of the research carried out show that the potential benefits deriving from the implementation of EN 9100, may be more intense as the time since the adherence to that standard is longer. Also, if the predominant motivations for such implementation are seeking internal positive effects, the benefits generated will be higher. On the other hand, obtaining such positive effects it is not influenced by the size of the companies in the aerospace sector.

Based on the above, the directors of the companies in this sector, regardless of the size, should consider the implementation and/or the maintenance of the standard EN 9100, with the 
economic costs that this decision involves, not only with the motivation to achieve the positive effect of meeting a requirement to compete and be included in global projects, but as a way to get real internal progress in the quality and the productivity of the work of their companies. These improvements are what ultimately will allow them to avoid heavy penalties and not to be excluded from contracts in the future, given the importance of both safety and quality of work, in this sector.

Also these companies must be aware that quality improvement is a long distance race, so once you finish the implementation of EN 9100 , it is necessary to continue investing resources, for the progressive consolidation in the company of the basic principles of this standard (continuous improvement, involvement of the entire company in the quality process, focus on customers, etc.). This way is more likely to get a higher level of positive effects, as a consequence of the adherence to the standard.

Therefore, this study allows to begin to cover the virtual nonexistence of studies related to the results of implementing quality assurance standards in the aerospace sector, as well as the factors that shall be considered by the directors of the companies that belong to this sector, with the purpose of obtaining the benefits derived from the implementation EN 9100 Standards, thus compensating the initial costs and maintenance of the adherence. Notwithstanding the foregoing, by the nature of the study carried out, the results must be interpreted with caution and be considered as approaches, until they can be confirmed with new empirical studies.

With respect to the future lines of investigation, the first of them, given the increasingly global character of this sector, would have to aim to extend the geographic scope of this study to the American and Asian the continent, thus results may be compared, and it could be determined whether this scope is a determining factor for the implementation of the standards, and for the appearance of the positive effects they can entail. Furthermore, another line of future investigation could consist on identifying the reasons for which the prevailing type of motivation (external/internal) is a significant variable for all the internal and external positive effects taken into account in this study, except for financial-commercial external effects. Finally, we must note that in this research respondents were quality managers of the participating companies, so their answers could be biased by a personnel interest of showing positive results generated by the implementation of EN 9100 . For this reason other future line of research, could be to extend the scope of the investigation to other groups involved, as others employees, customers and suppliers of the company.

\section{References}

Beltrán, J. (2002). El control de los dispositivos de seguimiento y medición en la norma EN 9100. Forum de Calidad, 135, 66-69.

Benner, M., \& Veloso, F. (2008). ISO 9000 practices and financial performance: a technology coherence perspective. Journal of Operations Management, 26(5), 611-629. doi:10.1016/j.jom.2007.10.005.

Bhuiyan, N., \& Alam, N. (2005). An investigation into issues related to the latest version of ISO 9000. Total Quality Management and Business Excellence, 8(1), 28-42. doi:10.1080/14783360500054343.

Boiral, O. (2001). Managing with ISO systems; lesson from practice. Long Range Planning, 44(3), 197-220. doi:10.1016/j. Irp.2010.12.003.

Boiral, O., \& Amara, N. (2009). Paradoxes of ISO 9000 performance: a configurational approach. The Quality Management Journal, 16(3), 36-60.

Braun, B. (2005). Building global institutions: the diffusion of management standards in the world economy - an institutional perspective. In C. Alvstam, \& E. Schamp (Eds.), Linking Industries across the World (pp. 3-27). London: Ashgate.

Briscoe, J., Fawcett, S., \& Todd, R. (2005). The implementation and impact of ISO 9000 among small manufacturing enterprises. Journal of Small Business Management, 43(3), 309330. doi:10.1111/j.1540-627X.2005.00139.x.

Calisir, F. (2007). Factors affecting service companies' satisfaction with ISO 9000. Managing Service Quality, 17(5), 579-593. doi:10.1108/09604520710817370.

Camison, C., Boronat, M., Villar, A., \& Puig, A. (2009). Sistemas de gestión de la calidad y desempeño: importancia de las prácticas de gestión del conocimiento y de I+D. Revista Europea de Dirección y Economía de la Empresa, 18(1), 123-134. 
Casadesus, M., \& Karapetrovic, S. (2005). Has ISO 9000 lost some of its lustre? A longitudinal impact study. International Journal of Operations \& Production Management, 25(5/6), 580-596. doi:10.1108/01443570510599737.

Chang, D., \& Lo, L. (2005). Measuring the relative efficiency of a firm's ability to achieve organizational benefits after ISO certification. Total Quality Management and Business Excellence, 16(1), 57-69. doi:10.1080/147833 6042000309866.

Climent, S. (2005). Los costes, gastos, burocracia e incremento de productividad por la certificación en la norma ISO 9000 en las empresas certificadas en la norma ISO 9000 de la Comunidad Valenciana. Investigaciones Europeas de Dirección y Economía de la Empresa, 11(1), 245-259.

Criado, F., \& Calvo, A. (2009). Factores clave y rendimiento en empresas españolas con sistemas de gestión de la calidad. Revista Europea de Dirección y Economía de la Empresa, 18(2), 107-126.

DBK (2012). Industria Aeroespacial. Resumen informe sectorial elaborado en Sept-2012. Retrieved from http://www.dbk.es/pdf/ sectores/sumarios/Industria\%20 Aeroespacial.pdf.

Dick, G., Heras, I., \& Casadesus, M. (2008). Shedding light on causation between ISO 9001 and improve business performance. International Journal of Operations and Production Management, 28(7), 687-708. doi:10.1108/01443570810881811.

Fonseca, L. A. (2013). Senior Managers and SMEs' Propensity to Quality Improvement. E\&M Ekonomie a Management, 16(4), 89-103.

Fotopoulos, C., \& Psomas, E. (2010). ISO 9001:2000 implementation in the Greek food sector. The TQM Journal, 22(2), 129-142. doi:10.1108/17542731011024255.

Gotzamani, K., \& Tsiotras, G. (2001). An empirical study of the ISO 9000 contribution towards total quality management. International Journal of Quality and Reliability Management, 21(9/10), 1326-1342. doi:10.1108/EUM0000000005972.

Gotzamani, K., Theodorakioglou, Y., \& Tsiotras, G. (2006). A longitudinal study of the ISO 9000 [1994] series' contribution towards TQM in Greek industry. The TQM Magazine, 18(1), 44-54. doi:10.1108/09544780610637686.

Grijalbo, M., \& Prida, B. (2005). La implantación de las normas EN 9100 y el esquema de certificación -Other Party- en
España. Revista Dyna Ingeniería e Industria, 80(8), 37-41.

Guler, I., Guillen, M., \& Macpherson, J. (2002). Global competition, institutions, and the diffusion of organizational practices: the international spread of ISO 9000 quality certificates. Administrative Science Quarterly, 47(2), 207-232. doi:10.2307/3094804.

Gustafsson, R., Kledsjo, B., Berggren, E., \& Gransfors-Wellements, U. (2001). Experiences from implementing ISO 9000 in small enterprises: a study of Swedish organizations. The TQM Magazine, 13(4), 232246. doi:10.1108/09544780110366088.

Gutierrez, E. (2008). UNE-EN 9100:2003. Gestión de la calidad en el sector aeronáutico. Forum Calidad, 197, 27-30.

Heras, I., \& Boiral, O. (2013). ISO 9001 and ISO 14001: towards a research agenda on Management System Standards. International Journal of Management Reviews, 15(1), 47-65. doi:10.1111/j.1468-2370.2012.00334.x.

International Aerospace Quality Group (IAQG). (2009). The EN 9100 Standard. Inglaterra: International Aerospace Quality Group Editions.

Instituto Andaluz Tecnológico (IAT). (2003). Guía para la aplicación de la Norma EN 9100 en las industrias del sector aeronáutico. Sevilla: Junta de Andalucía.

Juny, J. (2005). Calidad en el sector aeronáutico: UNE-EN 9100 una norma muy interesante. Forum de Calidad, 161, 39-43.

Karapetrovic, S., Fa, M., \& Heras, I. (2010). What happened to the ISO 9000 lustre? An eight-year study. Total Quality Management and Business Excellence, 21(3), 245-267. doi:10.1080/14783360903553149.

Lee, P., To, W., \& Yu, B. (2009). The implementation and performance outcomes of ISO 9000 in service organizations: an empirical taxonomy. International Journal of Quality and Reliability Management, 26(7), 646-662. doi:10.1108/02656710910975732.

Lo, L., \& Chang, D. (2007). The difference in the perceived benefits between firms that maintain ISO certification and those that do not. International Journal of Production Research, 48(5), 1881-1897. doi:10.1080/00207540600733709.

Lo, C., Yeung, A., \& Cheng, T. (2009). ISO 9000 and supply chain efficiency: Empirical evidence on inventory and account receivable days. International Journal of Production Economics, 118(2), 367-374. doi:10.1016/j.jpe.2008.11.010. 
Magd, H. (2008). ISO $9001: 2000$ in the Egyptian manufacturing sector: perceptions and perspectives. International Journal of Quality \& Reliability Management, 25(2), 173-200. doi:10.1108/02656710810846934.

Martinez-Costa, M., Martinez-Lorente, A., \& Choi, T. (2008). Simultaneous consideration of TQM and ISO 9000 on performance and motivation: An empirical study of Spanish companies. International Journal of Production Economics, 113(1), 23-39. doi:10.1016/j. ijpe.2007.02.046.

Martínez-Costa, M., Choi, T., Martínez, J., \& Martínez-Lorente, A. (2009). ISO 9000/1994, ISO $9001 / 2000$ and TQM: The performance debate revisited. Journal of Operations Management, 27(6), 495-511. doi:10.1016/j. jom.2009.04.002.

Mercado, C., Castillo, C., \& Mateo, A. (2005). La Normativa ISO 9000 como herramienta para incrementar el valor percibido por el cliente en las entidades financieras españolas. In F. Gonzalez, \& A. Terceño (Eds.), Simultaneidad Decisional y Multifocalidad Empresarial. A Coruña: AEDEM Ediciones.

Mugarra, P. (2005). La experiencia de SENER respecto a EN 9100. UNE-Boletín mensual AENOR, 176, 36-40.

Murga, J. (2002). Experiencia de ITP en Calidad. Revista Dyna de Ingeniería e Industria, 77(7), 32-36.

Pawliczek, A., \& Piszczur, R. (2013). Effect of Management Systems ISO 9000 and ISO 14000 on Enterprises' Awareness of Sustainability Priorities. E\&M Ekonomie a Management, 16(2), 66-79.

Prajogo, D. (2011). The role of firms motives in affecting the outcomes of ISO 9000 adoption. International Journal Operations \& Production Management, 31(1), 78-100. doi:10.1108/01443571111098753.

Psomas, E., Fotopoulos, C., \& Kafetzopoulos, D. (2010). Critical Factors for Effective Implementation of ISO 9001 in SME Service Companies. Managing Service Quality, 20(5), 440-457. doi:10.1108/09604521011073731.

Pricewaterhousecoopers (PwC). (2012). Aeroespace \& Defense: 2011 year in review and 2012 forecast. Retrieved from http://www. pwc.com/gx/en/aerospace-defence-and-security/ aerospace-defence-publications/aerospacedefence-2011-year-in-review-2012-forecast.jhtml.

Quazi, H., Hong, C., \& Meng, C. (2002). Impact of ISO 9000 certification on quality management practices: a comparative study. Total Quality Management and Business Excellence, 13(1), 53-67. doi:10.1080/09544120120098564.

Rodriguez-Escobar, J., Gonzalez-Benito, J., \& Martinez-Lorente, A. (2006). An analysis of the degree of small companies' dissatisfaction with ISO 9000 certification. Total Quality Management and Business Excellence, 17(4), 507-521. doi:10.1080/14783360500528304.

Sampaio, P., Saraiva, P., \& Rodrigues, A. (2009). ISO 9001 certification research: questions, answers and approaches. International Journal of Quality and Reliability Management. 26(1), 38-58. doi:10.1108/02656710910924161.

Tari, J., Molina-Azorin, J., \& Heras, I. (2012). Benefits of ISO 9001 and ISO 14001 standards: a literature review. Journal of Industrial Engineering Management. 5(2), 297-332. doi:10.3926/jiem.488.

TEDAE. (2010). Memoria de Actividades. Consultado el 13 de Julio de 2011. Retrieved from http://www.tedae.es/View/page/documentos/.

Terziovski, M., Power, D., \& Sohal, A. (2003). The longitudinal effects of the ISO 9000 certification process on business performance. European Journal of Operational Research, 146(3), 580-595. doi:10.1016/S03772217(02)00252-7.

Vilar, J. (2003). La implantación de la norma EN 9100 en EADS-CASA. UNE-Boletín mensual de AENOR, 177, 42-45.

Whitford, B., \& Bird, R. (1996). The pursuit of quality. Londres: Prentice Hall.

\section{Ph.D. Carlos del Castillo-Peces}

Rey Juan Carlos University Social and Legal Sciences Faculty Business Economics Department carlos.delcastillo@urjc.es

Ph.D. Carmelo Mercado-Idoeta

Rey Juan Carlos University Social and Legal Sciences Faculty Business Economics Department carmelo.mercado@urjc.es

Ph.D. Camilo Prado-Román

Rey Juan Carlos University Social and Legal Sciences Faculty Business Economics Department camilo.prado.roman@urjc.es 


\section{Abstract}

\section{DETERMINING FACTORS OF THE BENEFITS DERIVED FROM THE IMPLEMENTATION OF EN 9100 STANDARDS}

\section{Carlos del Castillo-Peces, Carmelo Mercado-Idoeta, Camilo Prado-Román}

In Spain, as well as in the rest of the world, the aerospace sector is one of the most important. The EN 9100 Standards (AS 9100 in America and SIAC 9100 in Asia), are a quality management system for the aerospace industry derived from the ISO 9001 standard, that include the requirements derived from the ISO 9001 and 83 specific additional requirements for the aerospace industry. This research aims to begin covering the virtual lack of studies about the results arising from the implementation of quality assurance standards in this sector. In particular, the objective of the research involves analyzing whether the appearance of the various positive effects that may arise as a result of implementing EN 9100 Standards is influenced by the following factors: a) size of the company; b) implementation of EN 9100 seniority; c) prevailing type of motivation (external and/ or internal) to adhere to such standards. To that end, the research was addressed to the Spanish aerospace sector, and the population subject to the investigation was defined by 317 companies. A questionnaire was sent by postal mail and e-mail to the directors of quality of all the selected companies, and a multiple linear regression model was applied to data from the 126 valid survey responses. The results show that EN 9100 adherence seniority, as well as the prevailing type of motivation (internal or external), are significant variables for the appearance of positive effects arising from the implementation of EN 9100, while the size of the company is non-significant for the emergence of such positive effects.

Key Words: Quality management, quality assurance standards, EN 9100 Standards, ISO 9001 Standard, Spanish aerospace industry.

JEL Classification: L15, M10.

DOI: 10.15240/tul/001/2017-1-005 